\title{
A high-resolution record of carbon accumulation rates during boreal peatland initiation
}

\author{
I. F. Pendea ${ }^{1, *}$ and G. L. Chmura ${ }^{1}$ \\ ${ }^{1}$ Department of Geography, McGill University \& Global Environmental and Climate Change Centre, Quebec, Canada \\ * now at: Department of Interdisciplinary Studies, Lakehead University - Orillia Campus, Orillia, Ontario, Canada
}

Correspondence to: G. L. Chmura (gail.chmura@mcgill.ca)

Received: 23 November 2011 - Published in Biogeosciences Discuss.: 25 January 2012

Revised: 21 June 2012 - Accepted: 25 June 2012 - Published: 25 July 2012

\begin{abstract}
Boreal peatlands are a major global C sink, thus having important feedbacks to climate. A decreased concentration in atmospheric $\mathrm{CO}_{2} 7000-10000 \mathrm{yr}$ ago has been linked to variations in peatland $\mathrm{C}$ accumulation rates attributed to a warm climate and increased productivity. Yet, this period also corresponds to early stages of peatland development (as peatland was expanding) following retreat of ice sheets and increases in $\mathrm{C}$ storage could be associated with wetland evolution via lake filling or following marine shoreline emergence. Unravelling past links amongst peatland dynamics, $\mathrm{C}$ storage, and climate will help us assess potential feedbacks from future changes in these systems, but most studies are hampered by low temporal resolution. Here we provide a decadal scale $\mathrm{C}$ accumulation record for a fen that has begun transformation from salt marsh within the last $70 \mathrm{yr}$ on the isostatically rebounding coast of James Bay, Québec. We determined time frames for wetland stages using palynological analyses to reconstruct ecological change and ${ }^{210} \mathrm{~Pb}$ and ${ }^{137} \mathrm{Cs}$ to date the deposit. The average short-term $\mathrm{C}$ accumulation rates during the low and high tidal marsh and incipient fen stage $\left(42,87\right.$ and $182 \mathrm{~g} \mathrm{C} \mathrm{m}^{-2} \mathrm{yr}^{-1}$, respectively) were as much as six times higher than the global longterm (millennial) average for northern peatlands. We suggest that the atmospheric $\mathrm{CO}_{2}$ flux during the early Holocene could be attributed, in part, to wetland evolution associated with isostatic rebound, which makes land for new wetland formation. Future climate warming will increase eustatic sea level, decrease rates of land emergence and formation of new coastal wetlands, ultimately decreasing rates of $\mathrm{C}$ storage of wetlands on rebounding coastlines.
\end{abstract}

\section{Introduction}

Boreal and Arctic peatlands constitute a major global $\mathrm{C}$ reservoir of 400-500 Gt (Roulet, 2000), but also release $\mathrm{CH}_{4}$ to the atmosphere - thus can have important feedbacks to climate (e.g., Yu et al., 2011). Post-glacial development of these boreal wetlands has played a key role in shifts of atmospheric concentrations of $\mathrm{CO}_{2}$ and $\mathrm{CH}_{4}$. Carbon sequestration histories in peat deposits have shown variations in peatland $\mathrm{C}$ accumulation rates over the Holocene that have been linked with a decreased concentration in atmospheric $\mathrm{CO}_{2} 7000$ $10000 \mathrm{yr}$ ago. This increased $\mathrm{C}$ storage has been attributed to climate change and increased productivity (MacDonald et al., 2006; Yu et al., 2011). However, this period also would have corresponded to early stages of peatland development following retreat of ice sheets and substantial increases in storage could be associated with wetland evolution via lake filling (e.g., Kubiw et al., 1989) or following marine shoreline emergence (e.g., Shennan et al., 1999, 2000; Pendea et al., 2010). Some northern peatlands originated as marine shorelines emerged from the sea, isostatically recovering from crustal depression caused by ice sheets (e.g., Shennan et al., 2000; Pendea et al., 2010). Immediately after emergence, tidal marsh deposits formed and, with continued crustal uplift, marshes were isolated from tidal influence and transformed into freshwater minerotrophic fens. Continued accumulation of peat eventually isolates the ecosystem from groundwater, making possible a shift from a fen to ombrotrophic bog. As wetland transition occurs, the rates of $\mathrm{C}$ storage in soils and greenhouse gas flux could change significantly. This change could be related to significant differences between moss-dominated fresh water peatlands and 
tidal wetlands, not just in plant species but in plant morphology and physiology. The carbon in freshwater peatland substrates is fixed primarily by mosses (Sphagnum spp. and brown mosses), which add plant mass to the surface (Clymo, 1984). When plants die, they begin to decay, mainly in aerobic conditions. In contrast, the primary source of carbon in tidal wetland soils is from vascular plants (e.g., grasses and sedges) which fix atmospheric carbon dioxide and translocate much of the fixed carbon to their roots and rhizomes. Most of the vascular plants found in tidal wetlands have aerenchymous tissue that serves as a gas conduit, transporting oxygen to their rhizomes (e.g., Burdick, 1989; Colmer and Flowers, 2008), which enable plant tissue to survive even within flooded soils. This living belowground biomass can penetrate as far as $40 \mathrm{~cm}$ into the soil (e.g., Connor and Chmura, 2000); therefore, carbon accumulation occurs throughout this zone. In tidal wetlands, there is more live biomass in the soil than above it, with ratios of live belowground (roots and rhizomes) biomass to aboveground biomass as high as 11 to 1 (e.g., Connor and Chmura, 2000; Darby and Turner, 2008; Chmura, 2009).

Modern tidal marshes globally store an average of $210 \mathrm{~g} \mathrm{C} \mathrm{m}^{-2} \mathrm{yr}^{-1}$ (Chmura et al., 2003); thus, wetland evolution associated with marine emergence could explain, at least in part, high $\mathrm{C}$ accumulation rates in the early Holocene. Sedimentary analysis of a tidal marsh we discovered in transition to a peatland suggests the need to broaden our considerations of carbon dynamics in the early history of boreal and subArctic peatlands.

Unravelling past links amongst peatland dynamics, $\mathrm{C}$ storage and climate will help us assess potential feedbacks from future changes in these ecosystems. Although immensely useful, most paleoecological studies have been limited to, at best, a centennial resolution in dating of ecosystem change (e.g., Yu et al., 2003). Deposits are dated with ${ }^{14} \mathrm{C}$, which commonly has an analytical error of 20 to $60{ }^{14} \mathrm{C} \mathrm{yr}$, and uncertainties in calendar years ranging from 100 to $300 \mathrm{yr}$ (Guilderson et al., 2005). In addition, peat deposits in tidal wetlands and peatlands are subject to autocompaction, as plant structure is lost with partial decay and loss of water held in tissue (Kaye and Barghoorn, 1964; Aaby and Tauber, 1975; Barber, 1981; Clymo, 1984; Cahoon et al., 1995) that increases with time, further decreasing potential temporal resolution of a sample of buried peat. Yet, decadal to centennial changes in $\mathrm{C}$ balance are the most relevant to climate change impact assessments and mitigation policies; a research theme that Yu et al. (2011) noted requires urgent attention. Decadal-scale $\mathrm{C}$ accumulation rates can be determined by dating surface deposits with the short-lived radioisotopes ${ }^{210} \mathrm{~Pb}$ and ${ }^{137} \mathrm{Cs}$ which have been used to determine rates in wetlands, such as freshwater fens (Craft et al., 2008) and tidal salt marshes (Chmura and Hung, 2004), which are easily located on the landscape.

However, determination of high-resolution $\mathrm{C}$ accumulation rates associated with early wetland evolution requires location of a fen that has transformed from salt marsh during a period within the limitation of ${ }^{210} \mathrm{~Pb}$-dating, the last $100-$ $200 \mathrm{yr}$, a condition not readily visible on the landscape. Boreal coastal regions presently undergoing isostatic rebound can provide such analogues and we located a site in early stages of peatland formation on the coast of James Bay, Québec. We used palynological analyses to reconstruct ecological changes, measured sediment $\mathrm{C}$ density, dated the deposits with ${ }^{210} \mathrm{~Pb}$ and ${ }^{137} \mathrm{Cs}$, and thus were able to document $\mathrm{C}$ accumulation rates at a sub-decadal scale.

\section{Materials and methods}

\subsection{Study area and sediment sampling}

Our site is located in the high boreal zone of eastern James Bay, northwestern Québec at $52.78^{\circ} \mathrm{N}, 78.76^{\circ} \mathrm{W}$. The region was covered by the last remnants of the Laurentide Ice Sheet until the early Holocene when marine waters invaded the newly deglaciated surface (Dyke et al., 2003). The marine transgression was brief and followed by shoreline regression under the influence of glacio-isostatic rebound. Over the last $\sim 7000 \mathrm{yr}$, landscape emergence has been underway at a rate ranging from $6.5 \mathrm{~m} / 100 \mathrm{yr}$ between 7000 and $6500 \mathrm{cal}$ yr BP to $1.4-2 \mathrm{~m} / 100 \mathrm{yr}$ during the late Holocene (Pendea et al., 2010).

The sampled wetland is bordered by steep slopes $(\sim 20$ $30^{\circ}$ ) vegetated with spruce trees (Picea mariana and Picea glauca). The basin holding the wetland is a former marine channel $\sim 150 \mathrm{~m}$-wide and $800 \mathrm{~m}$-long. A 1971 topographic map published by the Department of Energy, Mines, and Resources confirms that the site was then a tidal channel. During our field work in 2006, the channel was filled with emergent tidal wetland vegetation dominated by Carex paleacea, Juncus balticus and Schoenoplectus maritimus. However, salt-intolerant brown mosses were evident in small areas of the wetland. In one such area, we collected a $33 \mathrm{~cm}$-long sediment slab, retrieving all peat without compaction, by cutting it from the side of a pit. We worked during low tide when the water table was approximately $3 \mathrm{~cm}$ below the soil surface.

The soil slab was carefully packed to avoid compaction and loss of water and transported back to the lab where it was sectioned into 1-cm-thick layers. A subsample was cut from each slice for pollen analysis with $1.5 \mathrm{~cm}$ diameter metal cylinder, and the remaining sediment in each layer was dried, weighed to determine dry bulk density, then grounded for radionuclide and carbon analysis.

\subsection{Paleo-wetland analysis}

Pollen samples were processed as detailed by Pendea and Chmura (2012), and resulting assemblages were used to assess shifts in wetland environments over time by comparing them to a suite of modern analogues Pendea and Chmura (2012) developed for this region. The advantage of 
using pollen to reconstruct ecosystems is that it reflects a broader area than the small section of peat sampled and vegetation contemporaneous to the level sampled. Using discriminant analysis, we identified the highest similarity between a fossil sample and one of the a priori sample groups within the suite of modern analogues: low marsh, high marsh, fen, and bog. All discriminant analysis calculations and regression analyses were performed using IBM SPSS 19.0 (IBM Inc., 2011).

\subsection{Rates of sediment and carbon accumulation}

The radionuclides ${ }^{210} \mathrm{~Pb},{ }^{241} \mathrm{Am}$, and ${ }^{137} \mathrm{Cs}$ were analysed by direct gamma assay in the Liverpool University Environmental Radioactivity Laboratory using Ortec HPGe GWL series well-type coaxial low background intrinsic germanium detectors (Appleby et al., 1986). Enough slices (19 within the $31 \mathrm{~cm}$ ) were analysed for radionuclides to isolate a ${ }^{137} \mathrm{Cs}-$ peak and apply the CRS model (Appleby and Oldfield, 1978; Appleby et al., 1992) to calculate ${ }^{210} \mathrm{~Pb}$ dates.

The dating model was chosen following an assessment of the ${ }^{210} \mathrm{~Pb}$ and ${ }^{137} \mathrm{Cs}$ records determined for this core. Use of the CF : CS (constant flux: constant sedimentation rate) model was precluded by the presence of several significant deviations from a simple exponential decline in unsupported ${ }^{210} \mathrm{~Pb}$ concentrations. Use of the CIC (constant initial concentration) model was precluded by the presence of two significant non-monotonic features (one at the top of the core between $0-5 \mathrm{~cm}$ and the other much deeper, between 18 and $25 \mathrm{~cm}$ ). Mixing as a cause of the surficial non-monotonic feature was precluded by the presence of a well-resolved ${ }^{137} \mathrm{Cs}$ peak. Calculations using the CRS model alone placed 1963 at a depth of $16.5 \mathrm{~cm}$, in relatively good agreement with the depth of $13.5 \mathrm{~cm}$ suggested by the ${ }^{137} \mathrm{Cs}$ record. The discrepancy is most probably due to changes in the ${ }^{210} \mathrm{~Pb}$ supply rate associated with the transition from highly compacted clay sediments below $16 \mathrm{~cm}$ to low density peaty deposits above. Corrections to the CRS model were however made using the well-defined $1963{ }^{137} \mathrm{Cs}$ date as a reference point (Appleby, 2001).

The \% sedimentary organic $\mathrm{C}$ was determined either by loss-on-ignition (LOI) or on a Carlo Erba Na-1500 CNS Elemental Analyzer with a precision of $<0.2 \mu \mathrm{g}$. The latter method enabled us to determine and subtract the proportion of inorganic carbon from our calculations. For samples classified as tidal marsh, the LOI was converted to $\mathrm{C}$ using the formula developed by Craft et al. (1991). We performed LOI on all samples classified as fen. Fen samples that were analyzed by both methods were used to produce an equation to estimate \% C (\% organic $\mathrm{C}=0.512 \times \% \mathrm{LOI}-1.524)$ for the remaining fen samples. The linear regression of $\%$ LOI as a predictor for \% C produced an adjusted $R^{2}$ of 0.996 with $p=0.03$. Carbon density was calculated as a product of $\%$ organic $\mathrm{C}$ and bulk density. From these parameters and
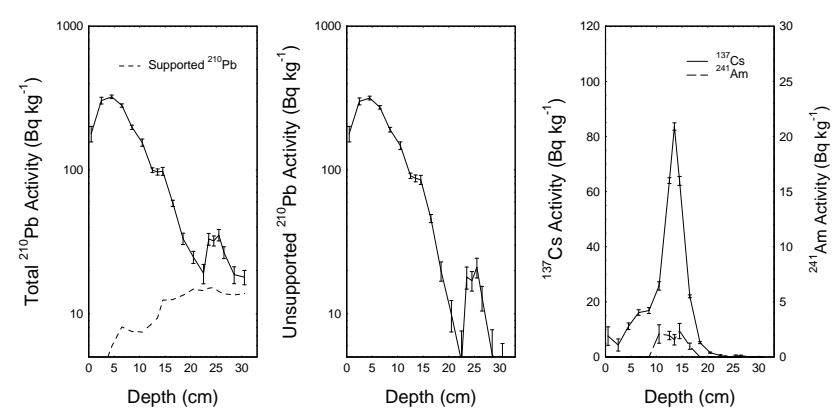

Fig. 1. Profiles of ${ }^{210} \mathrm{~Pb},{ }^{137} \mathrm{Cs}$, and ${ }^{241} \mathrm{Am}$, concentrations versus depth in a young fen from James Bay, Quebec.

sediment accumulation rates, we calculated $\mathrm{C}$ accumulation rates.

\section{Results and discussion}

\subsection{Rate of paleo-wetland evolution}

Our age model is derived by interpretation of ${ }^{210} \mathrm{~Pb},{ }^{241} \mathrm{Am}$, and ${ }^{137} \mathrm{Cs}$ profiles together (Fig. 1). Cesium-137 concentrations have a well- resolved peak at $13.5 \mathrm{~cm}$ depth which we date at 1963, the year that coincides with maximum atmospheric fallout due to production of this artificial radionuclide during the peak in above-ground testing of nuclear weapons (Pennington et al., 1973; Patrick and DeLaune, 1990). This interpretation is supported by the presence of significant concentrations of ${ }^{241} \mathrm{Am}$ at the same depth (Appleby et al., 1991). Lead-210 concentrations show a subsurface maximum at 2.5 to $4.5 \mathrm{~cm}$ depth. Below this depth, concentrations continuously decrease to $22.5 \mathrm{~cm}$ where they again increase within the tidal marsh phase (see below). The shallow subsurface increase is likely due to influx of $\mathrm{Pb}$ in runoff from adjacent slopes following a local fire in 1989. Palynological analyses reveal shifts from sub-tidal marine sediments to low-elevation tidal marsh, then high-elevation tidal marsh and eventually freshwater fen within the upper $25 \mathrm{~cm}$ (Fig. 2). Samples from 28 to $23 \mathrm{~cm}$ were classified as low marsh and above 23 to $5 \mathrm{~cm}$ were classified as high marsh, with the uppermost deposit classified as fen in our discriminant analysis of the palynological assemblages. The stratigraphic context constrains the $22-23 \mathrm{~cm}$ sample as the transition from low to high marsh, but it was classified as fen. However, the set of modern pollen analogues upon which our discriminant analysis was based does not include transitional communities; thus, there is a low probability $(11 \%)$ that an analogue for the $22-23 \mathrm{~cm}$ depth sample was in our data set.

Tidal marsh formation dates to $\sim 1885 \mathrm{AD}$, and the system existed as low-elevation tidal marsh for $\sim 45 \mathrm{yr}$ when elevation further increased relative to local sea level, tidal flooding decreased, and vegetation characteristic of high marsh became dominant. After another $\sim 65 \mathrm{yr}$, tidal influences 
Askuabaneskum Main Camp (AMC core), James Bay, Quebec

Analyst: I.F. Pendea

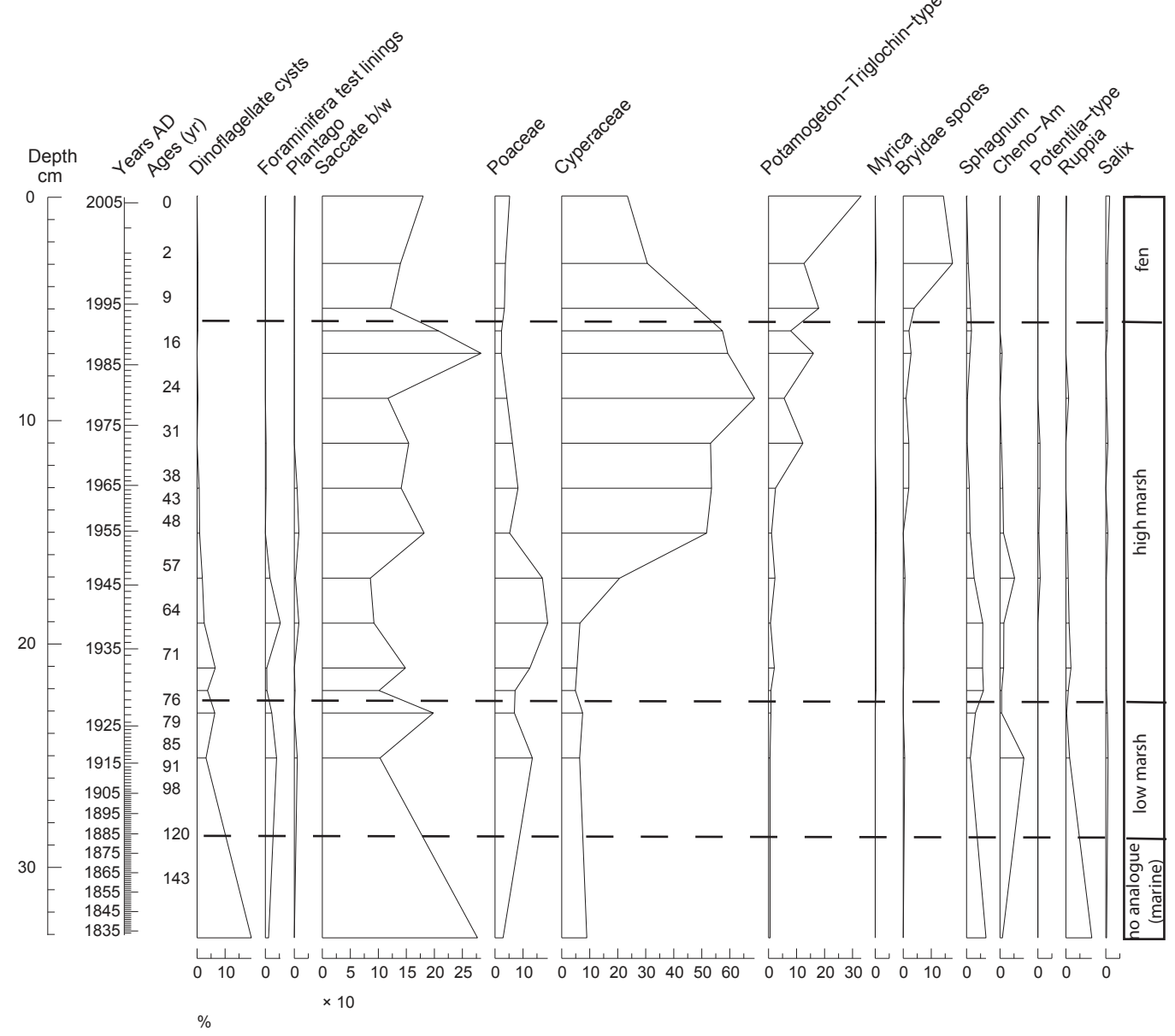

Fig. 2. Percentages of plant pollen, spores and dinoflagellate cysts used in the discriminant analysis classifying paleo-wetland communities determined within the AMC core from James Bay, Quebec. Percentages are based on a sum of all plant pollen and spores, excluding Sphagnum. The \% Saccate b/w, representing broken conifer pollen prevalent in tidal sediments, is multiplied by 10 for clarity. Note that the age axis, expressed in calendar years, is presented to correspond to appropriate depths, thus is not linear.

became negligible and the system shifted from high tidal marsh to freshwater fen in $\sim 1997 \mathrm{AD}$. This paleoecological interpretation fits with oral history which records the channel was still navigable by canoe during high tides in the early 1950s (F. Asquabaneskum, personal communication, 2006).

\subsection{Organic $\mathrm{C}$ accumulation rates}

To appropriately address carbon dynamics of peatlands, one must consider both sites of active carbon sequestration: the acrotelm (a $10-50 \mathrm{~cm}$ thick layer where carbon fixed during photosynthesis is first stored, but where decomposition rates are high), and the lower layers where decomposition of accumulated organic matter is slower, the catotelm. Although the concept of acrotelm and catotelm as applied by Clymo (1984) is relevant to bogs and nutrient poor fens (the wetlands commonly referred to as "peatlands"), we cannot directly apply this same dynamic to tidal wetlands, due to the difference in hydrological regime dominated by tidal fluctuations and predominance of vascular vegetation. In tidal wetlands, newly sequestered carbon is less prone to decomposition as compared to freshwater peatlands for three main reasons. First, new carbon in freshwater peatlands is generally introduced directly to oxidized soil layers. Although the rhizospheres may be oxidized in tidal wetlands, the soil surrounding the living biomass generally has a redox potential that falls below the threshold at which anaerobic respiration, which is less efficient than aerobic respiration, predominates. Thus, in tidal wetlands, carbon is directly introduced to the anaerobic soils further decreasing rates of decomposition. Second, the soil chemistry of tidal wetlands also contributes to slower decomposition rates. The salinity of the soil presents an osmotic stress to microbes responsible for decomposition. Thus, decomposition rates are lower in saline soils (e.g., Setia et al., 2011). Third, in freshwater 
peatlands, the water table is dominated by seasonal fluctuations, with a clear zonal differentiation between acrotelm and catotelm, whereas in tidal wetlands the water table fluctuates daily, rising and falling with the tides (Nuttle, 1988). These hydrological dynamics do not allow a clear functional differentiation of an acrotelm and catatelm in tidal wetlands. Also, daily water saturation of the wetland surface in tidal wetlands should further reduce decomposition as compared to freshwater peatlands, where oxidation of organic matter is enhanced during the seasonally low water table in the acrotelm.

Carbon accumulation rates are dependent upon soil bulk density, the \% C, and vertical soil accumulation rates (Fig. 3). Bulk density is highest in the early phase of the tidal marsh and decreases, with the exception of one fen sample, towards the surface. Carbon density is highest towards the middle of the high marsh phase. In contrast, soil accumulation rates are highest in the fen stage. These high accumulation rates largely drive the pattern of $\mathrm{C}$ accumulation, which averaged $42 \mathrm{~g} \mathrm{~m}^{-2} \mathrm{yr}^{-1}$ in the low marsh, $87 \mathrm{~g} \mathrm{~m}^{-2} \mathrm{yr}^{-1}$ in the high marsh and $182 \mathrm{~g} \mathrm{~m}^{-2} \mathrm{yr}^{-1}$ in the fen. The total organic $\mathrm{C} \mathrm{ac}-$ cumulated over the short history of the wetland is $8187 \mathrm{~g} \mathrm{~m}^{-2}$ with 593, 5555, and $2039 \mathrm{~g} \mathrm{~m}^{-2}$ accumulated in the low marsh, high marsh, and fen, respectively.

There are few rates of recent $\mathrm{C}$ accumulation in minerotrophic fens available for comparison. Craft et al. (2008) used ${ }^{137} \mathrm{Cs}$ to examine peat accumulation rates along a latitudinal gradient in the United States and reported $\mathrm{C}$ accumulation rates of $28-47 \mathrm{~g} \mathrm{C} \mathrm{m}^{-2} \mathrm{yr}^{-1}$ in a Minnesota fen and $19-56 \mathrm{~g} \mathrm{~m}^{-2} \mathrm{yr}^{-1}$ in two Florida fens. Both of these rates are roughly comparable to the global long-term average for northern freshwater peatlands, $20-30 \mathrm{~g} \mathrm{C} \mathrm{m}^{-2} \mathrm{yr}^{-1}$ reported by Roulet (2000). The fens examined by Craft et al. (2008) were 30 to 37-yr- old, thus subject to longer periods of decomposition.

Besides reflecting reduced periods available for decomposition, higher $\mathrm{C}$ accumulation rates also may be characteristic of young fens, a property that merits considerably more research. Young fens are likely to have a higher nutrient status as they still can be affected by nutrients in ground and surfaces waters, whereas bogs are hydrologically isolated from these nutrient sources. Since the nutrient status of fens could accelerate rates of peat production, future studies also should examine decomposition rates in salt marsh-to-fen transitions.

\subsection{Peatland initiation and the Early Holocene $\mathrm{CO}_{2}$ anomaly}

Rapid expansion of circumarctic peatlands between 12 and $8 \mathrm{ka}$ has been linked to the early Holocene sustained $\mathrm{CH}_{4}$ peak and a decrease in atmospheric $\mathrm{CO}_{2}$ (Smith et al., 2004; MacDonald et al., 2006). The widespread expansion of peatlands has been attributed to high summer insolation and increasing temperatures. However, a closer look at the early peatland initiation processes, as exemplified here, suggests that patterns of carbon storage in early successional stages a

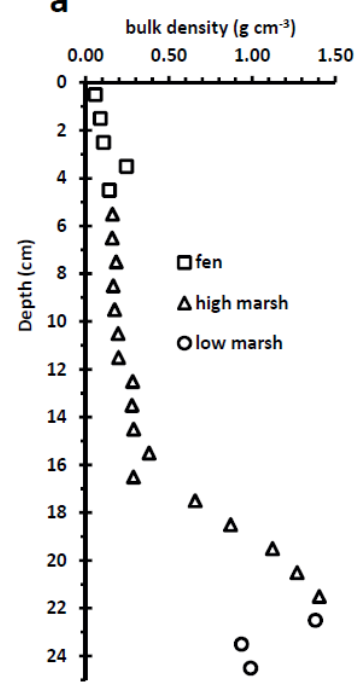

C

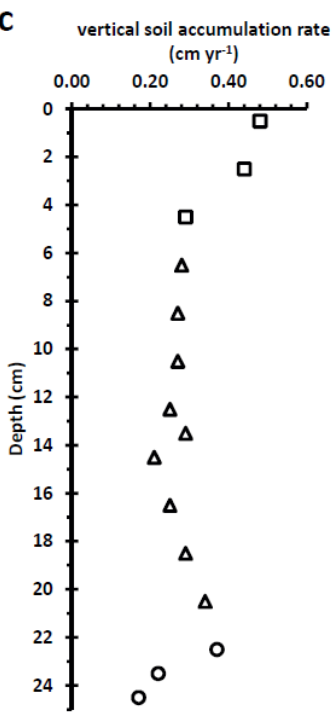

b

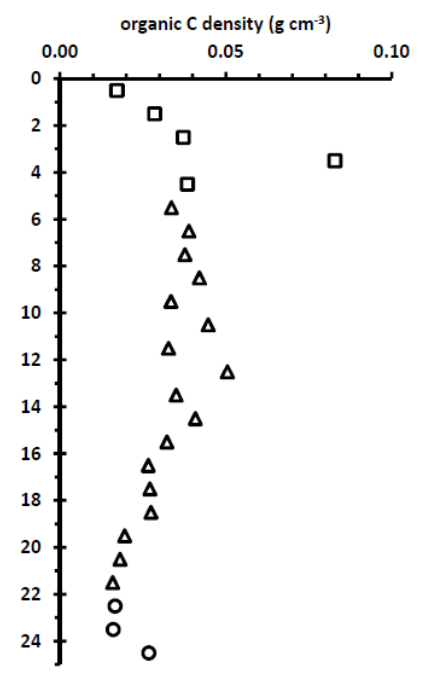

d

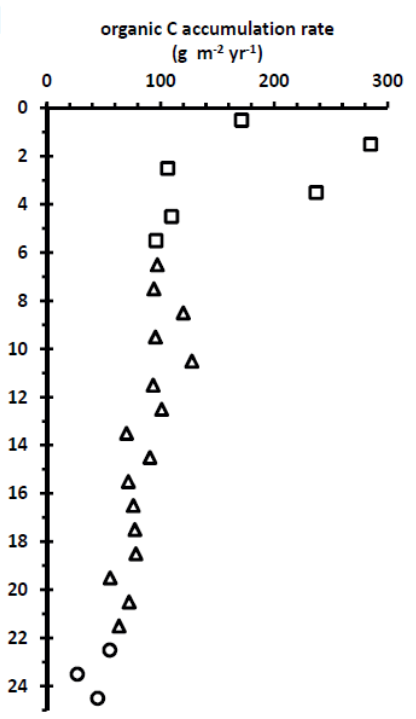

Fig. 3. Profiles of soil bulk density, carbon density, rates of vertical soil accumulation, and rates of $\mathrm{C}$ accumulation with depth in wetland deposits of the AMC core from James Bay, Quebec.

should be considered in addition to climate or nutrient availability, as suggested by Yu et al. (2011). Naturally, the peatland initiation model on former marine surfaces like the one presented here cannot have a global-scale relevance unless it applies to large peatland areas. Using the data on the probable extent of land submerged by ancient seas in northern North America during the early Holocene (Andrews, 1973) and the current wetland area (Commission for Environmental Cooperation, 2005), we calculate that peatland development on rebounding marine surfaces could have occurred over $\sim 330000 \mathrm{~km}^{2}$, representing $\sim 27 \%$ of the total Canadian peatland area. This figure represents the maximum area of peatland that may have originated from tidal wetlands in 
Canada, alone. Indeed, some of these wetlands could have originated in lake basins, such as kettle basins, but studies show that large blanket areas of peatlands such as those occupying the Hudson Bay Lowlands developed from tidal marshes which followed the marine water retreat (Glaser et al., 2004; Pendea et al., 2010). Although more work is needed, we suggest that the high carbon sequestration capacity of the early postglacial fens that succeeded tidal wetlands after the shoreline retreat may explain, in part, the early Holocene reduction in atmospheric $\mathrm{CO}_{2}$. Many of these fens were later succeeded by ombrotrophic bogs, but evidence suggests that early (post emergence) fen ecosystems remained active for a significant period of time after land emergence - in fact, the bog phase did not follow the salt marsh phase until after as much as $2500 \mathrm{yr}$ in southern James Bay (Glaser et al., 2004).

\section{Conclusions}

Our study indicates that rapid rebound could correspond to rates six times higher than long-term (millennial) global averages reported for $\mathrm{C}$ accumulation in northern peatlands. Those long-term averages should not be used as an indicator of peatland carbon sequestration rates that were simultaneous to the decrease in atmospheric carbon dioxide reflected in the ice core record. Although higher $\mathrm{C}$ storage rates may be characteristic of young fens, we suggest that the high rates of $\mathrm{C}$ accumulation reported for the early Holocene might, in part, be due to geomorphic changes, i.e., tidal wetlands forming as land emerged with isostatic rebound - and we feel that our initial report demonstrates the need for further research on this phenomenon.

The links we suggest among isostatic changes, wetland succession, and $\mathrm{C}$ accumulation rates have implications for future feedbacks to climate. Rates of subsequent fen formation are dependent upon both rates of isostatic rebound and eustatic sea level rise. With no change in eustatic rise, slower rates of rebound would slow transition from tidal marsh to fen, reducing $\mathrm{C}$ accumulation rates, while continued peat accumulation in many existing fens would isolate them from nutrient bearing groundwater, transform them to bogs and further reduce the rate of $\mathrm{C}$ storage. Increased rates of eustatic rise will have the same effect, and climate warming increases eustatic sea level in two ways - by increasing meltwater input to oceans and through thermal expansion of ocean water. Thus, the initial evidence we present here suggests that global warming may result in decreased rates of $\mathrm{C}$ storage of coastal wetlands on James Bay and other rebounding coastlines.

Acknowledgements. This work was part of the European Science Foundation EUROCORES Programme BOREAS and was supported by funds from SSHRC and NSERC. A GSA Graduate Student Research Grant to IFP provided funding for radionuclide analyses. We thank the people of the Wemindji Cree First Nation, in particular F. Asquabaneskum for help and guidance. We appreciate the many contributions of J. Sayles that were essential to our success in the field and our calculations of wetland area. We are grateful to P. Appleby for editorial assistance and anonymous reviewers whose comments helped us to improve the manuscript.

Edited by: J. Kesselmeier

\section{References}

Aaby, B. and Tauber, H.: Rates of peat formation in relation to humification and local environment, as shown by studies of a raised bog in Denmark, Boreas, 4, 1-17, 1975.

Andrews, J. T.: Maps of the Maximum Postglacial Marine Limit and Rebound for the former Laurentide Ice Sheet (the National Atlas of Canada), Arctic Alpine Res., 5, 41-48, 1973.

Appleby, P. G.: Chronostratigraphic techniques in recent sediments, Tracking Environmental Change Using Lake Sediments, Volume 1 Basin Analysis, Coring and Chronological Techniques, edited by: Last, W. M. and Smol, J. P., 171-204, 2001.

Appleby, P. G. and Oldfield, F.: The calculation of ${ }^{210} \mathrm{~Pb}$ dates assuming a constant rate of supply of unsupported ${ }^{210} \mathrm{~Pb}$ to the sediment, Catena, 5, 1-8, 1978.

Appleby, P. G., Nolan, P. J., Gifford, D. W., Godfrey, M. J., Oldfield, F., Anderson, N. J., and Battarbee, R. W.: $210 \mathrm{~Pb}$ dating by low background gamma counting, Hydrobiologia, 141, 21-27, 1986.

Appleby, P. G., Richardson, N., and Nolan, P. J.: Self-absorption corrections for well-type germanium detectors, Nucl. Inst. Methods B, 71, 228-233, 1992.

Barber, K. E.: Peat stratigraphy and climate change: a paleoecological test of the theory of cyclic peat bog regeneration, Rotterdam, Balkema, 1981.

Burdick, D. M.: Root aerenchyma development in Spartina patens in response to flooding, Am. J. Bot., 76, 777-780, 1989.

Cahoon, D. R., Reed, D. J., and Day, J. W.: Estimating shallow subsidence in microtidal salt marshes of the southeastern United States: Kaye and Barghoorn revisited, Mar. Geol., 128, 1-9, 1995.

Chmura, G. L.: Tidal Salt Marshes, in: The management of natural costal carbon sinks, edited by: Laffoley, D. d'A. and Grimsditch, G., IUCN, Gland, Switzerland, 53 pp., 2009.

Chmura, G. L. and Hung, G.: Controls on salt marsh accretion: a test in salt marshes of Eastern Canada, Estuaries, 27, 70-81, 2004.

Chmura, G. L., Anisfeld, S., Cahoon, D., and Lynch, J.: Global carbon sequestration in tidal, saline wetland soils, Global Biogeochem. Cy., 17, 1-12, 2003.

Clymo, R. S.: The limits to peat bog growth, Phil. Trans. R. Soc. Lond. B, 303, 605-654, 1984.

Colmer, T. D. and Flowers, T. J.: Flooding tolerance in halophytes, New Phytol., 179, 964-974, 2008.

Commission for Environmental Cooperation: North American Land Change Monitoring System, available at: http://www.cec.org/Page.asp?PageID=924\&ContentID=

2819\&AA_SiteLanguageID $=1$ (last access: 5 September 2011), 2005.

Connor, R. F. and Chmura, G. L.: Dynamics of above- and belowground organic matter in a high latitude macrotidal saltmarsh, Mar. Ecol. Prog. Ser., 204, 101-110, 2000. 
Craft, C. B., Seneca, E. D., and Broome, S. W.: Loss on ignition and Kjeldahl digestion for estimating organic carbon and total nitrogen in estuarine marsh soils: Calibration with dry combustion, Estuaries, 14, 175-179, 1991.

Craft, C., Washburn, C., and Parker, A.: Latitudinal trends in organic carbon accumulation of temperate freshwater peatlands, in: Wastewater Treatment, Plant Dynamics and Management in Constructed and Natural Wetlands, edited by: Vymazal, J., Springer Science and Business Media B. V., New York, 23-31, 2008.

Darby, F. D. and Turner, R. E.: Effects of eutrophication on salt marsh root and rhizome biomass accumulation, Mar. Ecol. Prog. Ser., 363, 63-70, 2008.

Dyke, A. S., Moore, A., and Robertson, L.: Deglaciation of North America, Open File Report 1574, Geological Survey of Canada, 2003.

Glaser, P. H., Hansen, B. C. S., Siegel, D. I., Reeve, A. S., and Morin, J. P.: Rates, pathways and drivers for peatland development in the Hudson Bay Lowlands, northern Ontario, Canada, J. Ecol., 92, 1036-1053, 2004.

Guilderson, T. P., Reimer, P. J., and Brown, T. A.: The boon and bane of radiocarbon dating, Science, 307, 362-364, 2005.

IBM SPSS Inc.: IBM SPSS Base 19.0 for Windows User's Guide, IBM SPSS Inc, Chicago, 2011.

Kaye, C. A. and Barghoorn, E. S.: Late Quaternary sea-level change and crustal rise at Boston, Massachusetts, with notes on the autocompaction of peat, Geol. Soc. Am. Bull., 75, 63-80, 1964.

Kubiw, H., Hickman, M., and Vitt, D. H.: The developmental history of peatlands at Muskiki and Marguerite lakes, Alberta, Can. J. Botany, 67, 3534-3544, 1989.

MacDonald, G. M., Beilman, D. W., Kremenetski, K. V., Sheng, Y., Smith, L., and Velichko, A. A.: Rapid early development of circumarctic peatlands and atmospheric $\mathrm{CH}_{4}$ and $\mathrm{CO}_{2}$ variations, Science, 314, 285-288, 2006.

Nuttle, W. K.: The extent of lateral water movement in the sediments of a New England salt marsh, Water Resour. Res., 24, 2077-2085, 1988.
Patrick Jr., W. H. and Delaune, R. D.: Subsidence, accretion and sea level rise in south San Francisco Bay marshes, Limnol. Oceanogr., 35, 1389-1395, 1990.

Pendea, I. F. and Chmura, G. L.: Calibration of pollen assemblages and carbon-nitrogen ratios to discriminate boreal wetland types, Rev. Palaeobot. Palyno., 174, 48-56, 2012.

Pendea, I. F., Costopoulos, A., Nielsen, C., and Chmura, G. L.: A new shoreline displacement model for the last $7 \mathrm{ka}$ from Eastern James Bay, Canada, Quaternary Res., 73, 474-484, 2010.

Pennington, W., Cambray, R. S., and Fisher, E. M.: Observations on lake sediments using fallout ${ }^{137} \mathrm{Cs}$ as a tracer, Nature, 242, 324-326, 1973.

Roulet, N. T.: Peatlands, carbon storage, greenhouse gases, and the Kyoto Protocol: Prospects, and significance for Canada, Wetlands, 20, 605-615, 2000.

Shennan, I., Tooley, M., Green, F., Innes, J. B., Kennington, K., Lloyd, J. M., and Rutherford, M. M.: Sea level, climate change and coastal evolution in Morar, northwest Scotland, Geologie en Mijnbouw, 77, 262-274, 1999.

Shennan, I., Lambeck, K., Horton, B., Innes, J. B., Lloyd, J. M., McArthur, J., Purcell, T., and Rutherford, M. M.: Late Devensian and Holocene records of relative sea-level changes in northwest Scotland and their implications for glacio-hydro-isostatic modelling, Quaternary Sci. Rev., 19, 1103-1135, 2000.

Setia, R., Marschner, P., Baldock, J., Chittleborough, D., and Verma, V.: Relationships between carbon dioxide emission and soil properties in salt-affected landscapes, Soil Bio. Biochem., 43, 667674, 2011.

Smith, L. C., MacDonald, G. M., Velichko, A. A., Beilman, D. W., Borisova, O. K., Frey, K. E., Kremenetski, K. V., and Sheng, Y. Siberian peatlands a net carbon sink and global methane source since the Early Holocene, Science, 303, 353-356, 2004.

Yu, Z., Vitt, D. H., and Campbell, I. D.: Understanding Holocene peat accumulation pattern of 10 continental fens in western Canada, Can. J. Botany, 81, 267-282, 2003.

Yu, Z., Beilman, D. W., Frolking, S., MacDonald, G. M., Roulet, N. T., Camill, P., and Charman, D. J.: Peatlands and their role in the global carbon cycle, EOS, 92, 97-98, 2011. 